DOI 10.22460/infinity.v7i2.p109-122

\title{
THE DEVELOPING MATH ELECTRONIC MODULE WITH SCIENTIFIC APPROACH USING KVISOFT FLIPBOOK MAKER PRO FOR XI GRADE OF SENIOR HIGH SCHOOL STUDENTS
}

\author{
Aulia Fonda $^{1}$, Sumargiyani ${ }^{2}$ \\ ${ }^{1,2}$ Universitas Ahmad Dahlan, Jl. Kapas No.9, Umbulharjo, Yogyakarta, Indonesia \\ 1 auliafonda@gmail.com, ${ }^{2}$ sumargiyani04@yahoo.com
}

Received: December 07, 2017 ; Accepted: June 01, 2018

\begin{abstract}
This study aims to determine the feasibility of learning media electronic module (e-module) based on Kvisoft Flipbook Maker Pro on derivative material with Scientific approach using Research and Development research methodology. The study was conducted in two schools by taking 4 students as a student response in small classes and 20 students in a large class. The research instrument used in the form of evaluation formative form of teaching materials for material experts, media experts, and student responses. From the result of the assessment of expert material instrument obtained an average score of 101.25 with very good criteria, the assessment of expert media instruments obtained an average score of 116 with good criteria as well as on student response instruments obtained 86.44 with very good criteria. These results indicate that the e-module of mathematics with the scientific approach of the derived material for the XI class of the even semester high school is worthy of use in the process of learning in the classroom.
\end{abstract}

Keywords: E-module, Derivative, Scientific, Kvisoft Flipbook Maker.

\begin{abstract}
Abstrak
Penelitian ini bertujuan untuk mengetahui kelayakan media pembelajaran elektronik modul (e-modul) berbasis software Kvisoft Flipbook Maker Pro pada materi turunan dengan pendekatan Scientific menggunakan metodologi penelitian Research and Development. pada materi turunan dengan pendekatan Scientific menggunakan metodologi penelitian Research and Development. Penelitian ini dilakukan di dua sekolah dengan mengambil 4 siswa sebagai respon siswa pada kelas kecil dan 20 siswa pada kelas besar. Instrumen penelitian yang digunakan berupa lembar evaluasi formatif bahan ajar untuk ahli materi, ahli media, dan respon siswa.Dari hasil penilaian instrumen ahli materi diperoleh skor rata-rata 101,25 dengan kriteria sangat baik, penilaian instrumen ahli media diperoleh skor rata-rata 116 dengan kriteria baik serta pada instrumen respon siswa diperoleh 86,44 dengan kriteria sangat baik. Hasil tersebut menunjukkan bahwa e-modulmatematika dengan pendekatan saintifik materi turunan untuk kelas XI SMA semester genap layak digunakan dalam proses pembelajaran di kelas.
\end{abstract}

Kata Kunci: E-modul, Turunan, Saintifik, Kvisoft Flipbook Maker

How to Cite: Fonda, A., \& Sumargiyani, S. (2018). The Developing Math Electronic Module with Scientific Approach using Kvisoft Flipbook Maker Pro for XI Grade of Senior High School Students. Infinity, 7(2), 109-122. doi:10.22460/infinity.v7i2.p109-122. 


\section{INTRODUCTION}

Education is an effort to develop the potential of students. Education is a learning process that can produce expected behavioral changes. The development of science and technology increasingly encourages renewal efforts in the utilization of technology results in the learning process. Teachers are required to be able to use the tools that can be provided by the school, and do not rule out that the tools are in accordance with the times. Teachers can at least use cheap and efficient tools which, though simple, are necessary in order to achieve the intended teaching objectives (Arsyad, 2011). Learning is a process of interaction between several components including learning subjects, learning objects learned, and learning media.

Learning media is a means of communication used to convey messages or learning materials, to attract students 'interest on learning materials and improve students' understanding of the material presented (Nuroifah, 2015). Learning by using media in teaching and learning process has two important roles, namely: (1) Media as teaching aid and (2) Media as learning resource used by self by learners independently, so that learning media have various benefits that can be used during teaching and learning process (Setyono, Afri, \& Deswita, 2017). Currently teachers in Indonesia who are literate ICT ranged from 10\%-15\%, this data shows that of the more than 2.7 million teachers in Indonesia, it is estimated that at most $15 \%$ of teachers are able to exploit the potential of ICT in the learning process. Student learning outcomes show a significant difference between learning without media and learning using media. Therefore, the use of learning media in teaching and learning process is highly recommended to enhance the quality of learning including computer media. Learning mediabased learning places the participants to interact directly with the learning materials in accordance with the capabilities and interests of the participants (Fadli, Suharno, \& Musadad, 2017). Learning media that can be developed one of them is teaching materials. Teaching materials can be developed for teachers to be used by students such as modules. In the previous research has been developed electronic module with statistics for class VII SMP / MTs with scientific approach expressed feasible use in learning process. (Marla \& Suparman, 2015). e-module creation can be developed with some existing applications. Previous studies have developed a kvisoft flipbook maker-based learning medium that is considered feasible with a percentage of media validation results kvisoft flipbook maker obtaining $86.67 \%$.

Mathematics is one of the subjects studied at all levels of education. At the level of primary and secondary education mathematics is included in the basic group that should be mastered by learners because of the importance of mathematics at the level of primary and secondary education is then the subjects of mathematics ranks first in this case the number of lessons (Kintoko \& Sujadi, 2015). For students the material that includes elusive material in mathematics is derivative. Derived material is one material that has a very wide range of applications both in mathematics itself, as well as in other branches of science such as in the fields of science, technology, economics and so on (Megariati, 2014). Learning Derivative material still has not achieved the expected achievement of student learning outcomes is still low. Therefore, improvement efforts are needed that can change the conditions in the learning (Rokhman, 2014). Many facts in the field still indicate that mathematics learning is only seen as a monotonous and procedural activity, that is the teacher explains the material, gives an example, assigns the student to do the exercise questions, checks the student's answers in passing, then discusses the solution of the problem which is then exemplified by the students (Ngilawajan, 2013). Teachers have the duty and responsibility optimally able to carry out the learning activities well marked by the high student activeness. Kakaktifan students in question is the involvement of students in carrying out activities ranging from discussion of concepts, 
the process of finding solutions to the conclusion of the concepts learned (Sinurat, Syahputra, \& Rajagukguk, 2015).

Based on the results of interviews of teachers of SMA Negeri 8 Yogyakarta and SMA Negeri 5 Yogyakarta said that the 2013 Curriculum print book issued by the Government is still limited, no teacher develops modules, especially in electronic form on mathematics subjects, students rely more on LKS and powerpoint from teachers in learning process, and lack of reference exercise questions for students. In the derivative and integral material some students are also not very interested because the built-in mindset says that the material is complicated by the number of descriptions, each form is different in completion and in further discussion the derivation is divided into trigonometric derivatives which are also very varied formulas. Moreover in the curriculum of 2013 students do not have mathematical textbooks that match and these materials require additional references. Students also need to practice a lot of questions in accordance with the 2013 curriculum with a scientific approach so that students are more active in the learning process.

Based on the mentioned problems, the success of learning activities to improve student learning outcomes is investigated in the following research questions: (a) The design of emodule learning media using Kvisoft Flipbook Maker Pro software on derived material and (b) the feasibility of the emodule media.

A study aimed at producing electronic module instructional media design (e-module) on derivative material for high school XI class students and to know the eligibility of e-module electronic learning media in derivative material for high school XI grade students that can improve student learning outcomes theoretical is expected to contribute to the development of science in supporting the world of education, especially in the learning of mathematics and the benefits can practically improve the skills in developing an interesting learning media and fun, especially in math lessons.

\section{METHOD}

The research development used is the method of Research and Development (R \& D). Research development is a research method to develop a new product or refine an existing product and can be accounted for. This study involved 4 students of class XI MIPA 5 and 20 students of class XI MIPA 7 in SMA Negeri 8. For in SMA Negeri 5 Yogyakarta research involves 4 students of class XI IPA 2 and 20 students class XI IPA 6. Instruments used in the form of observation sheet, questionnaires, and interview guides. Data collection techniques used in the form of observation, giving questionnaires, and interviews. While the data analysis techniques are: a) Qualitative data, in the form of criticism and input from material experts and media experts obtained from the validation. In addition, there is also e-module feasibility data obtained from questionnaire analysis of feasibility test of material experts, media experts and student response questionnaire to e-module.b) Quantitative data in the form of score of emodification feasibility test result by material expert, media expert and also score of questionnaire result of student response to the product.

Questionnaire assessment is developed and developed based on an evaluation component that includes 1) content feasibility, 2) language, 3) presentation, 4) kegrafikan. Based on the above criteria, a questionnaire grid for media expert feasibility test, feasibility test of the material expert and student response to e-module with several indicators, among others: 
Table 1. Indicator

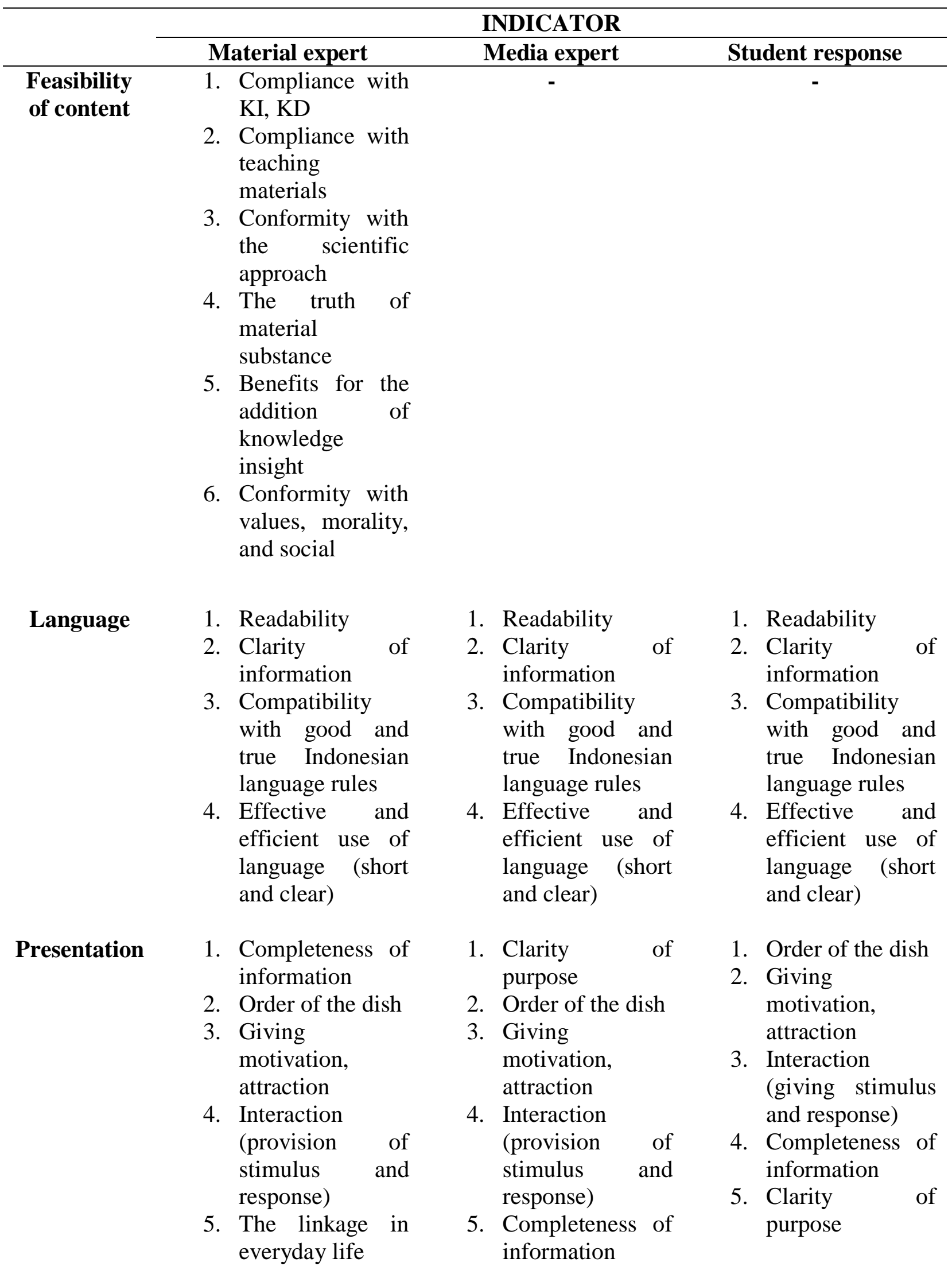




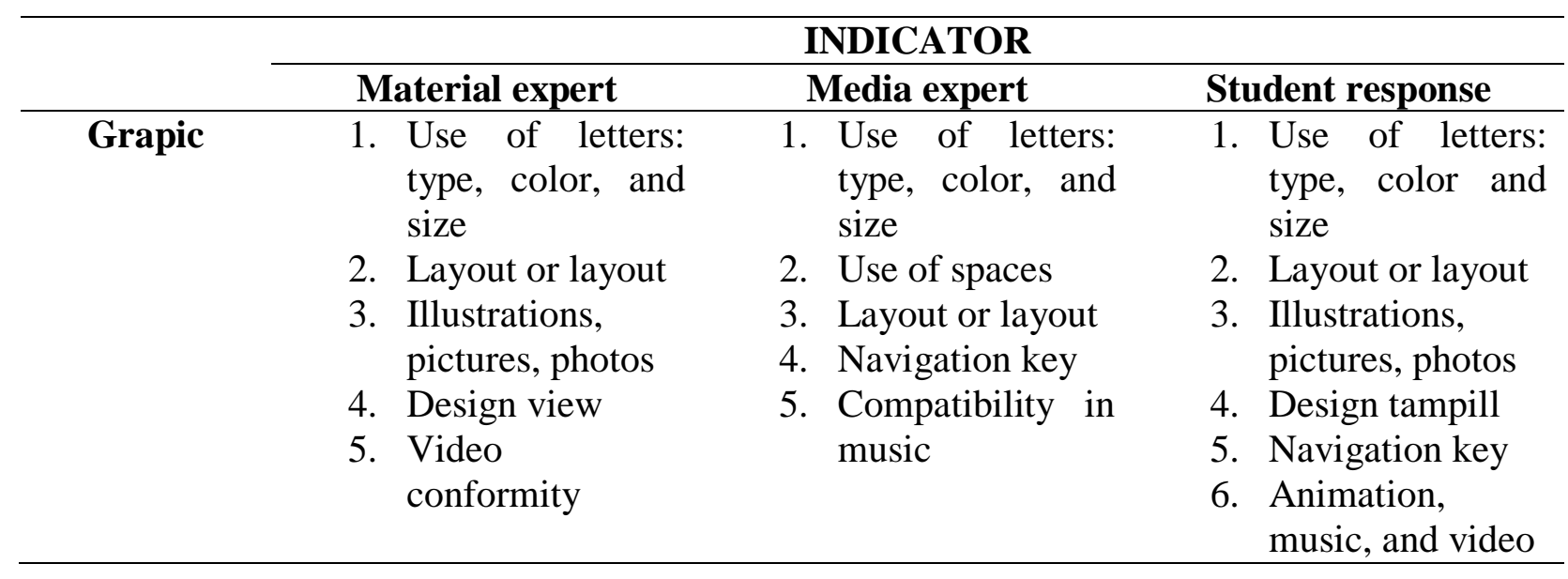

Data that has been obtained through a questionnaire by expert assessment of products and students in the form of qualitative value will be converted into quantitative values Likert scale.

Table 2. Likert Scale

\begin{tabular}{cc}
\hline Information & Score \\
\hline SS (Very Angree) & 5 \\
S (Agree) & 4 \\
CS (Enough Agree) & 3 \\
TS (Disagree) & 2 \\
STS (Very Disagree) & 1 \\
\hline
\end{tabular}

from the data that has been collected, we calculate the average by the formula:

$$
\bar{X}=\frac{\sum_{i=1}^{n} X_{i}}{n}
$$

This development research focused on the development of electronic module or e-module using Kvisoft Flipbook Maker Pro software derived by scientific approach packaged in CD (Compact Disc). Development of this media through several stages to obtain the feasibility of media e-module that can be used (Figure 1).

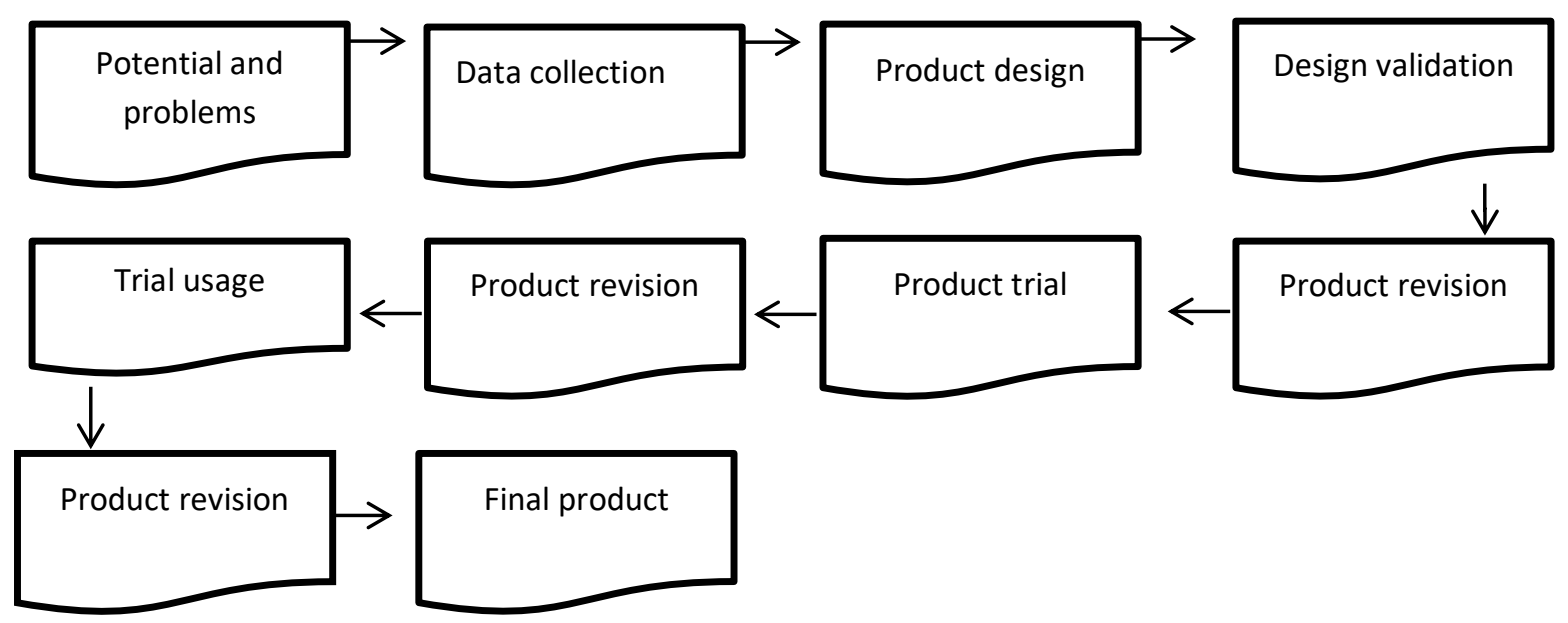

Figure 1. Step of Research and Development Method (R\&D) 
The data obtained from both media experts, material experts and students is transformed into qualitative values based on ideal assessment criteria. The ideal scoring criteria are shown in Table 2 below:

Table 3. Covertion Category Quantitative Data to Qualitative Data

\begin{tabular}{cc}
\hline Interval Score & Criteria \\
\hline$X>\bar{X}_{l}+1.80 S B_{i}$ & Very good \\
$\bar{X}_{l}+0.6 S B_{i}<X \leq \bar{X}_{\iota}+1.80 S B_{i}$ & Good \\
$\bar{X}_{l}-0.6 S B_{i}<X \leq \bar{X}_{l}+0.6 S B_{i}$ & Enough \\
$\bar{X}_{\iota}-1.80 S B_{i}<X \leq \bar{X}_{l}-0.6 S B_{i}$ & Not good \\
$X \leq \bar{X}_{l}-1.80 S B_{i}$ & Very poor \\
\hline
\end{tabular}

Information:

$\bar{X}_{l}=\frac{1}{2} \times(\max$ ideal score + min ideal score $)$

$S B_{i}=\frac{1}{6} \times($ max ideal score - min ideal score $)$

Where

$X \quad=$ empirical score

$X_{i} \quad=$ ideal mean

$S B_{i} \quad=$ ideal standart deviation

In data analysis to find the feasibility of this product, the highest score is 5 and the lowest score is 1 .

\section{RESULTS AND DISCUSSION}

\section{Results}

The development of e-module learning media using kvsoft flipbook maker pro software has gone through several stages of revision in accordance with the steps of $\mathrm{R} \& \mathrm{D}$ method. Determination of feasibility test using 3 questionnaire instrument that is questionnaire of feasibility of material expert, media expert, and student response. Questionnaire used as a quantitative e-modification feasibility test data. Questionnaire obtained and calculated, then adjusted to the criteria above categories. From questionnaires material experts, media experts, and student responses are obtained the following calculations:

Table 4. Result Calcuting Questionnaires Feasibility of Materials Expert

\begin{tabular}{cccc}
\hline No & Expert & Score & Quantitative Data Criteria \\
\hline 1. & Expert 1 & 114 & Very Good \\
2. & Expert 2 & 96 & Good \\
3. & Expert 3 & 99 & Good \\
4. & Expert 4 & 96 & Good \\
\hline & Average & $\mathbf{1 0 1 . 2 5}$ & Very Good \\
\hline
\end{tabular}

Based on the results of product quality assessment, it shows that the e-module is judged in terms of material by expert 1 material experts are included in the criteria are very good and include good criteria by expert 2, teacher of mathematics class XI SMA Negeri 8 Yogyakarta stated e-module including both criteria and teacher of mathematics study class of SMA Negeri 
5 Yogyakarta stated e-module including good criteria. The average results of the assessment in terms of the material included in the category is very good.

Table 5. Result Calcuting Questionnaires Feasibility of Media Expert

\begin{tabular}{cccc}
\hline No & Expert & Score & $\begin{array}{c}\text { Quantitative Data } \\
\text { Criteria }\end{array}$ \\
\hline 1. & Expert 1 & 116 & Good \\
2. & Expert 2 & 116 & Good \\
3. & Expert 3 & 116 & Good \\
\hline & Average & $\mathbf{1 1 6}$ & Good \\
\hline
\end{tabular}

Based on the results of product quality assessment, indicating that the e-module is assessed in terms of media by lecturers of media experts included in the criteria of good, teachers of mathematics study of SMA Negeri 8 Yogyakarta stated e-module including both criteria and teacher of mathematics study of SMA Negeri 5 Yogyakarta stated e-modules include good criteria. Average results of assessment in terms of media include in good category.

Table 6. Result Calcuting Questionnaires Feasibility of Student Response

\begin{tabular}{cccc}
\hline No. & School & Average & $\begin{array}{c}\text { Quantitative Data } \\
\text { Criteria }\end{array}$ \\
\hline 1. & SMA Negeri 8 Yogyakarta & 87,52 & Very Good \\
2. & SMA Negeri 5 Yogyakarta & 85,37 & Very Good \\
\hline & Average & $\mathbf{8 6 , 4 4}$ & Very Good \\
\hline
\end{tabular}

Based on the questionnaire results of student responses, indicating that the e-modules that have been developed included in the very well category.

Table 7. Results Calculation Questionnaire and Questionnaire of Student Response

\begin{tabular}{clcc}
\hline No. & Aspects of Assessment & Average & Quantitative Data Criteria \\
\hline 1. & Material Expert & 101,25 & Very Good \\
2. & Media Expert & 116 & Good \\
3. & Student Response & 86,44 & Very Good \\
\hline
\end{tabular}

Based on the results of the questionnaire assessment and student response questionnaire, it shows that the e-module is included in the criteria is very good for use in the learning process by the material experts and student responses as well as good criteria for media experts.

\section{Discussion}

Trial data in developing electronic module (e-module) math derivative material for XI grade even semester SMA based on curriculum 2013 with scientific approach using Kvisoft Flipbook Maker Pro software. The results of this product is packaged in the form of CD (Compact Disk). This development is structured by the steps of the use of Research and Development (Sugiyono, 2011). 
Potentials and problems especially in math lessons and the availability of mathematics emodule XI class in high school that some students still think mathematics difficult to understand, there is no teacher who uses and develop e-module as a source of learning mathematics students, as for computers and internet network in the school has not been maximally utilized as a student learning media with a scientific approach. From description above can be arranged a map of needs in the manufacture of e-module. The researcher developed a mathematical e-module derived material for an even semester grade XI class based on the 2013 curriculum with a scientific approach. The development of e-module derived material begins by designing e-module products. Stages of product design are emodule writing in accordance with the Guidance of Development Guide and in accordance with the Writing Module (Arsyad, 2011). Making this product using Microsoft Word 2010, Corel Draw Suite X5, Geogebra, Nitro PDF, Macromedia Flash and Kvisoft Flipbook Maker Pro. The resulting product is then revised by material and media experts then tested to students. Here's the display of the results of each design, namely:

\section{Cover}

The cover view of the e-module contains the author's name, title, supporting material of derived material, subjects, and usage goals. While the cover on the back contains the author's profile. The front and rear cover cover of the e-module can be seen in figure 2 and figure 3 .

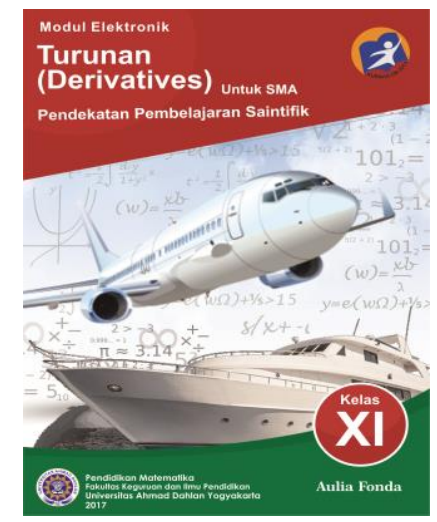

Figure 2. Front Cover

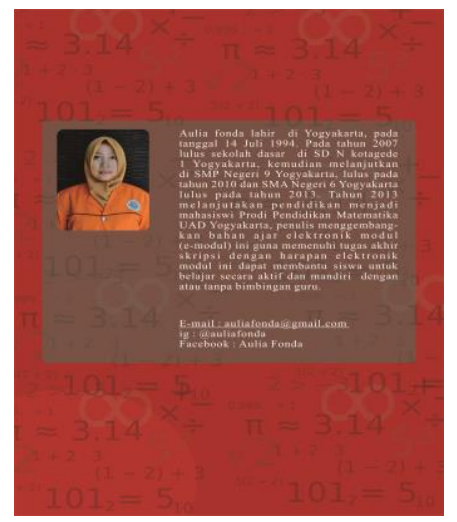

Figure 3.Back Cover

\section{Title page}

The cover cover of the e-module contains the title, author name, mentor name, editor name, cover design name, software used and name of agency. Display page title can be seen in figure 4 .

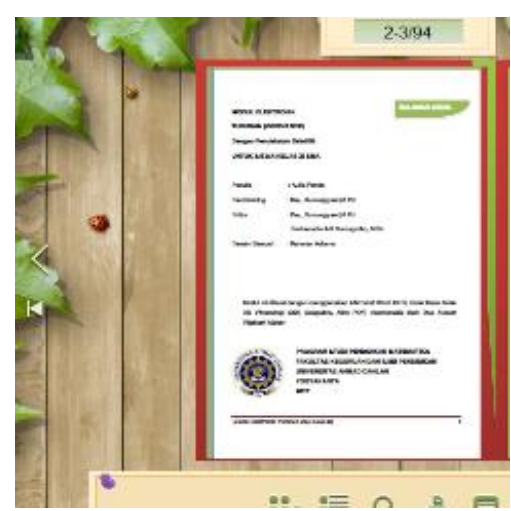

Figure 4. Title Page 


\section{Foreword}

Contains gratitude for the completion of the e-module of mathematics material Class XI grade even grade semester based on the 2013 curriculum with a scientific approach and a brief explanation of the contents of the e-module. The introductory view can be seen in figure 5 .

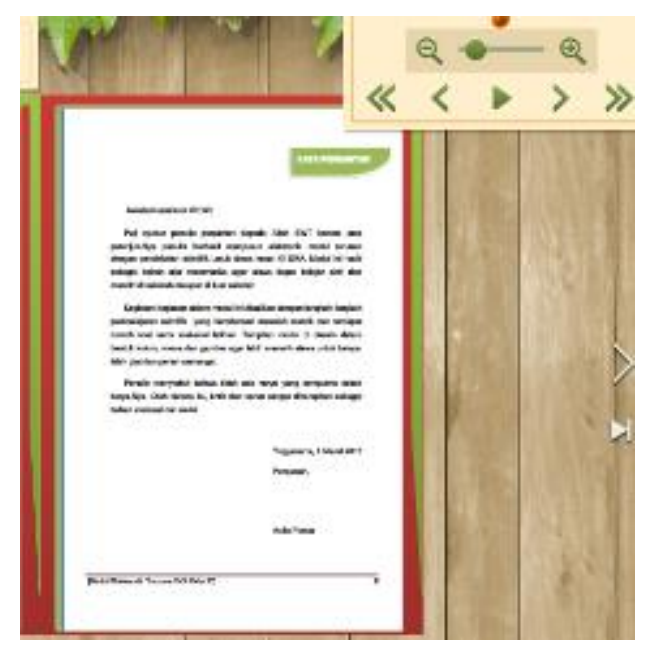

Figure 5. Foreword e-modul

\section{Table of content}

The table of contents helps the users of the e-module to find the desired page and is useful for knowing all the things contained in the e-module. The table of contents view can be seen on figure 6 .

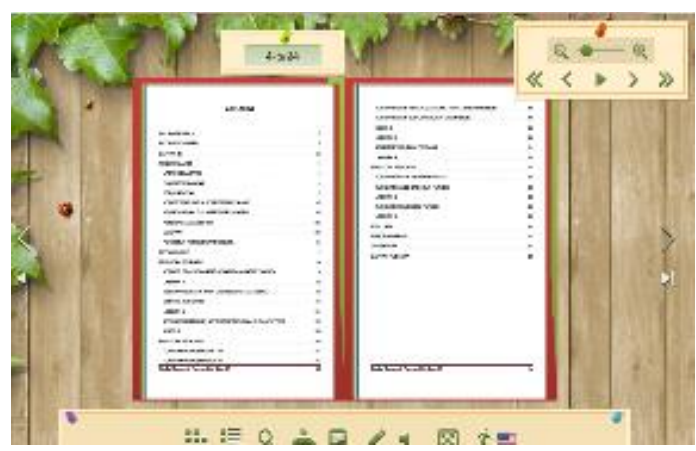

Figure 6. Table of content

\section{Preliminary}

Introduction contains brief descriptions, requirements, Core Competencies, Basic Competencies, activities, learning objectives, scientific approaches, benefits, and usage instructions. The preliminary view can be seen on figure 7 .

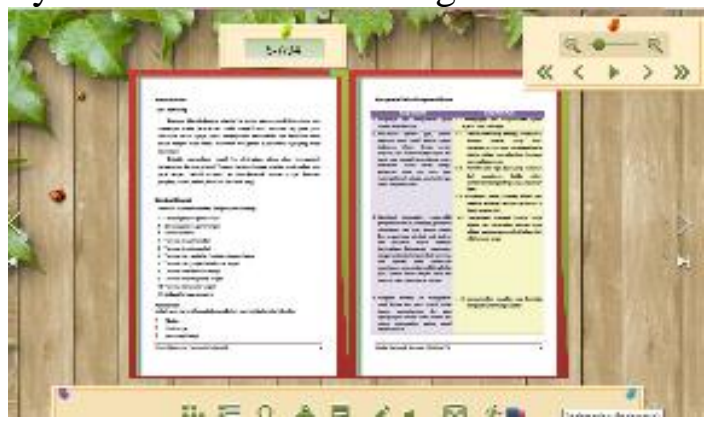

Figure 7. Preliminary e-modul 
118 Fonda, \& Sumargiyani, The Developing Math Electronic Module with Scientific ...

\section{Concept maps}

The e-module concept map contains the learning activity structure that e-module users will learn. The concept map view can be seen on figure 8 .

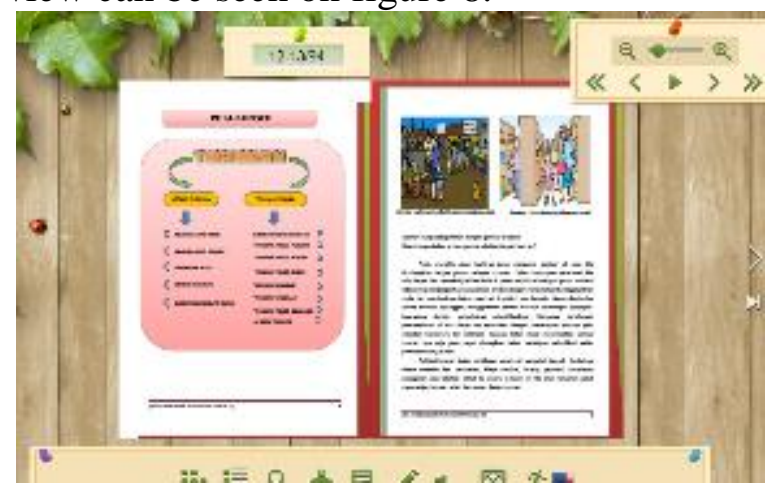

Figure 8. Concept maps

\section{Learning activities}

In this learning activity is divided into three parts namely learning activities 1, learning activities 2, and learning activities 3.Display each learning activity can be seen on figure 9(i), 9(ii), and 9(iii).

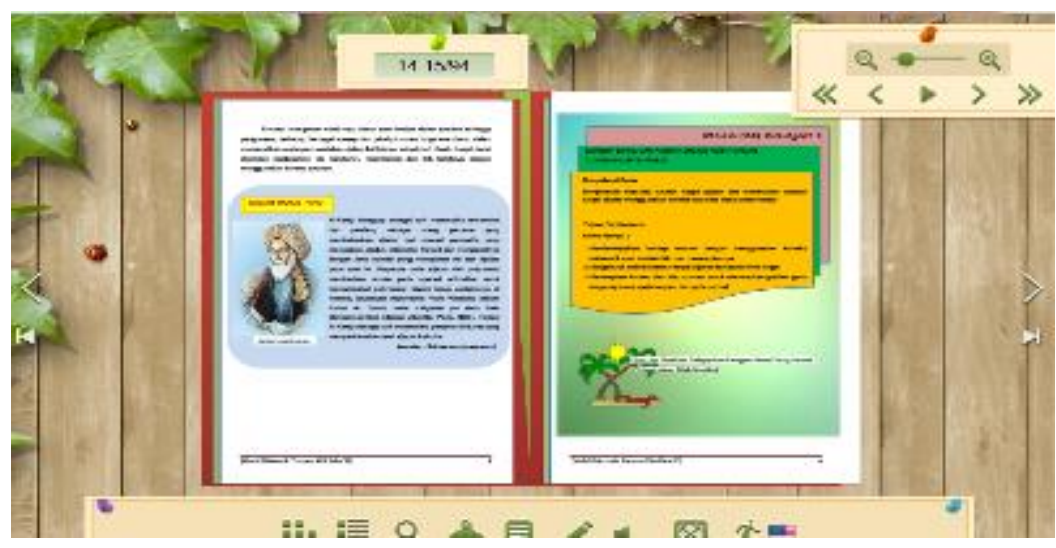

Figure 9(i). Learning activites 1

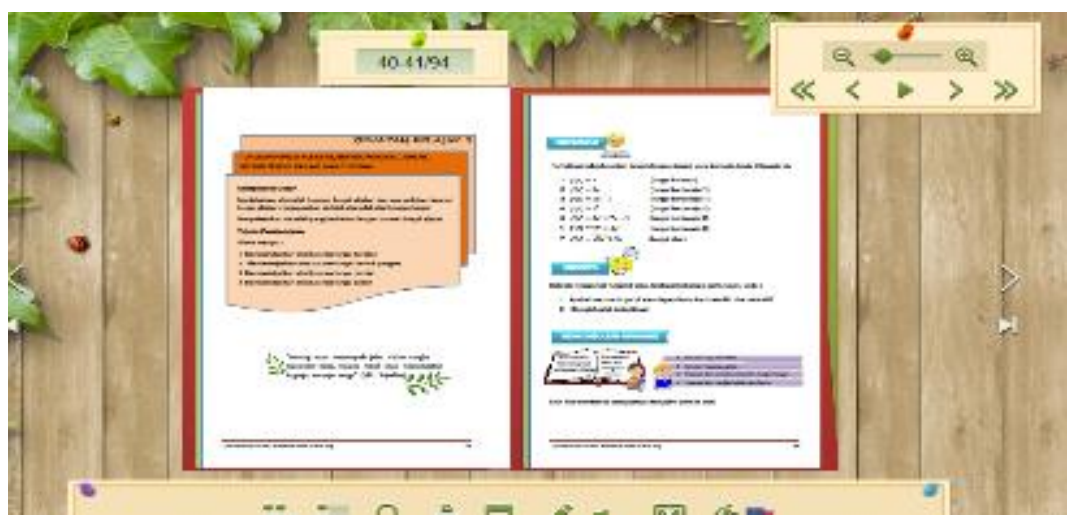

Figure 9(ii). Learning activites 2 


\section{Evaluation}

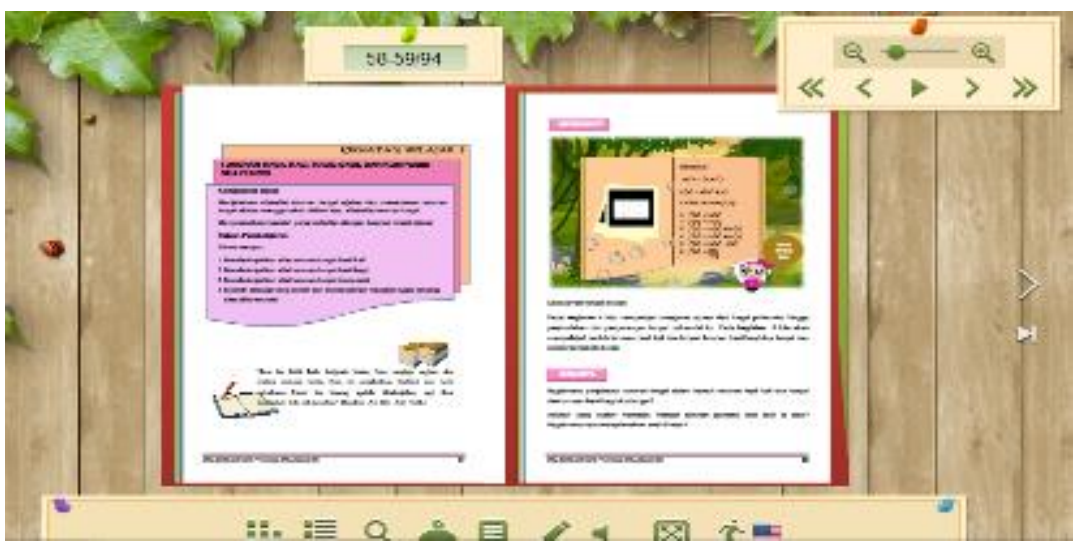

Figure 9(iii). Learning activites 3

This evaluation is made using macromedia flash, so that e-module users are facilitated in doing and calculating the scores of evaluations that have been done. The evaluation view can be seen on figure 10 .

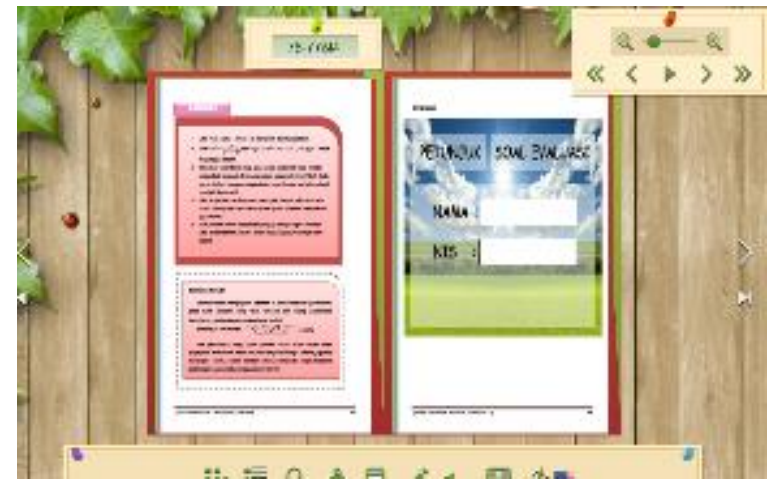

Figure 10. Ealuation

\section{Answer keys and glossary}

This final section contains answer keys, glossary and bibliography.Can be seen on figure 11(i) and 11(ii).

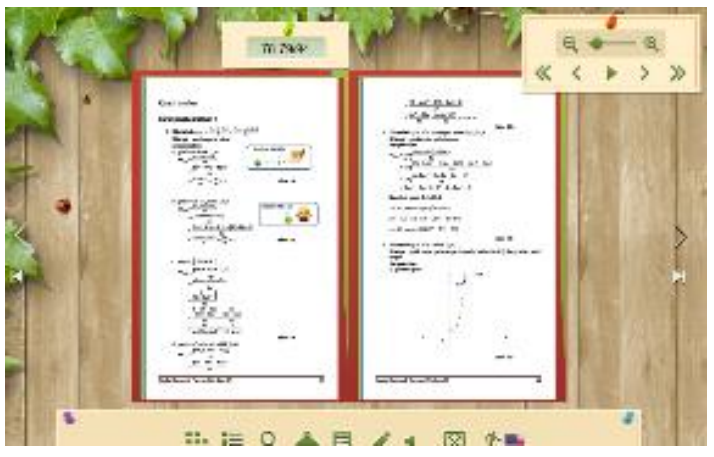

Figure 11(i). Answer Keys 


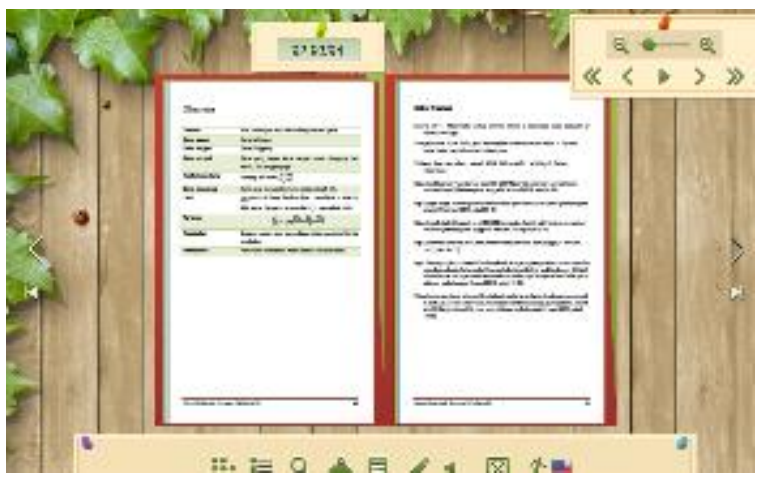

Figure 11(ii). Glossary

The trial procedure is by presenting e-module in computer and students enthusiastically using e-module and actively doing question and answer to the researcher. The researcher guides the process of product testing with the accompanying math teacher. The researcher also provided a little explanation of the material presented on the e-module. Furthermore, the researcher distributed the assessment sheet in form of formative evaluation instrument instrument and the students fill out the assessment sheet. This assessment sheet aims to determine the student's response to e-modules that have been developed.

Overall, the result of the research shows that e-module can be used. The result of questionnaire obtained is processed into a quantitative data in the form of average score calculation. From table 8 it can be seen that the e-module developed by the researcher entered the category very well so that the e-module is feasible to be used in the learning process both accompanied by the teacher and used as learning independently.

\section{CONCLUSION}

The feasibility of mathematical e-module products using Kvisoft Flipbook Maker Pro software derived material for class XI SMA based on the 2013 curriculum with scientific approach developed included in very good category based on the calculation result of average composite score of material experts of 101.25 and good category of the media experts of 116 and the category is very good from the average score of student response is 86.44 . So that the mathematics e-module material derived class XI SMA semester evenly based on the 2013 curriculum with scientific approach worthy of use in the process of learning in the classroom.

\section{REFERENCES}

Arsyad, A. (2011). Media Pembelajaran. Jakarta: Rajawali pers Depdiknas. 2003.

Fadli, A., Suharno, S., \& Musadad, A. A. (2017). Deskripsi Analisis Kebutuhan Media Pembelajaran Berbasis Role Play Game Education untuk Pembelajaran Matematika. In Prosiding Seminar Nasional Teknologi Pendidikan.

Kintoko, K., \& Sujadi, I. (2015). Pengembangan Media Pembelajaran Matematika Berbantuan Komputer dengan Lectora Authoring Tools pada Materi Bangun Ruang Sisi Datar Kelas VIII SMP/MTs. Jurnal Pembelajaran Matematika, 3(2).

Marla, A., \& Suparman. (2015). Pengembangan E-modul Matematika Materi Statistika Untuk Kelas VII SMP/MTs dengan Pendekatan Saintifik. AdMathEdu, 355-361. 
Megariati, M. (2014). Peningkatan Hasil Belajar Matematika Pada Materi Turunan Fungsi Menggunakan Teknik Probing Prompting Di Kelas XI IPA 1 Sekolah Menengah Atas Negeri 2 Palembang. Jurnal Pendidikan Matematika, 5(1).

Ngilawajan, D. A. (2013). Proses Berpikir Siswa SMA dalam memecahkan masalah matematika materi turunan ditinjau dari gaya kognitif field independent dan field dependent. PEDAGOGIA: Jurnal Pendidikan, 2(1), 71-83.

Nuroifah, N. (2015). Pengembangan Media Pembelajaran Berbasis Aplikasi Android Materi Sistem Ekskresi Siswa Kelas XI SMA Negeri 1 Dawarblandong Mojokerto. Jurnal Mahasiswa Teknologi Pendidikan, 1(1).

Rokhman, N. (2014). Multimedia Pembelajaran Turunan Bernuansa Konstruktivisme dan Problem Solving. Indonesian Digital Journal of Mathematics and Education. 1(1):112.

Setyono, T., Afri, L. E., \& Deswita, H. (2017). Pengembangan Media Pembelajaran Matematika Dengan Menggunakan Macromedia Flash Pada Materi Bangun Ruang Kelas VIII Sekolah Menengah Pertama. Jurnal Ilmiah Mahasiswa FKIP Prodi Matematika, 2(1).

Sinurat, M., Syahputra, E., \& Rajagukguk, W. (2015). Pengembangan Media Pembelajaran Matematika Berbantuan Program Flash untuk Meningkatkan Kemampuan Matematik Siswa SMP. Jurnal Tabularasa, 12(02).

Sugiyono (2011). Metode Penelitian Pendidikan (Pendekatan Kuantitatif, Kualitatif, dan $R \& D)$. Bandung: Alfabeta. 
122 Fonda, \& Sumargiyani, The Developing Math Electronic Module with Scientific ... 